\title{
Optimally achieving milk bulk tank somatic cell count thresholds
}

\author{
Jason A. Troendle, ${ }^{*}$ Loren W. Tauer, ${ }^{* 1}$ and Yrjo T. Gröhn† \\ ${ }^{*}$ Charles H. Dyson School of Applied Economics and Management, Cornell College of Business \\ †Section of Epidemiology, Department of Population Medicine and Diagnostic Sciences, College of Veterinary Medicine, Cornell University, \\ Ithaca, NY 14853
}

\section{ABSTRACT}

High somatic cell count in milk leads to reduced shelf life in fluid milk and lower processed yields in manufactured dairy products. As a result, farmers are often penalized for high bulk tank somatic cell count or paid a premium for low bulk tank somatic cell count. Many countries also require all milk from a farm to be lower than a specified regulated somatic cell count. Thus, farms often cull cows that have high somatic cell count to meet somatic cell count thresholds. Rather than naively cull the highest somatic cell count cows, a mathematical programming model was developed that determines the cows to be culled from the herd by maximizing the net present value of the herd, subject to meeting any specified bulk tank somatic cell count level. The model was applied to test-day cows on 2 New York State dairy farms. Results showed that the net present value of the herd was increased by using the model to meet the somatic cell count restriction compared with naïvely culling the highest somatic cell count cows. Implementation of the model would be straightforward in dairy management decision software. Key words: bulk tank somatic cell count, shelf life, culling, mathematical model

\section{INTRODUCTION}

Dairy farm income is affected by penalties or by premiums for achieving bulk tank SCC greater or lower, respectively, than a specific threshold set by milk processors. These penalties or premiums are used to encourage farmers to meet SCC thresholds because SCC affects the shelf life of fluid milk and the yield efficiency in manufactured milk products such as cheese (Barbano et al., 2006). Bulk tank SCC is determined by taking a milk sample from the bulk tank on the day milk is collected from the farm. All lactating cows in the herd contribute to the milk load in the tank, but individual cows vary in their individual SCC concentrations. One

Received June 7, 2016.

Accepted October 5, 2016.

${ }^{1}$ Corresponding author: lwt1@cornell.edu straightforward way to meet any set threshold would be to cull all cows that individually have an SCC above the threshold until the tank threshold is met. Although that approach would meet the constraint on bulk tank SCC, some cows eliminated from the herd might be high performers and extremely profitable to the farm, both in the quantity of milk they produce at low cost and in the genetics that they contribute to the herd. Thus, it may be optimal to keep some cows with high SCC concentrations in the herd even if they individually exceed the SCC threshold, but these retained cows would have to be offset by culling other cows with SCC still above the threshold level.

Because of the relationship between the incidence of mastitis and high SCC, the decision to cull a cow because of mastitis often eliminates high SCC cows. Because mastitis is linked to higher SCC, the 2 will be interconnected in trying to reach a farm-wide SCC threshold. The ability to predict recurrence of clinical mastitis and associated costs if consistent and accurate records are available may play a key role in culling models (Lehenbauer and Oltjen, 1998). Past models have focused on culling practices derived from the cost of testing for mastitis (Zepeda et al., 1998), treating mastitis and cost of mastitis (Allore et al., 1998; Allore and Erb, 1998; Bar et al., 2008), and the dollar value of production on a per cow basis (Lehenbauer and Oltjen, 1998). However, many cows experience high SCC with little or no evidence of mastitis and may be extremely valuable. They may still be culled from the herd to meet a bulk tank SCC threshold. A rule of thumb often used is to cull, sequentially, the highest SCC cows until the bulk tank threshold is met. However, the objective of the farmer should be to retain the cows that result in the greatest net profit while simultaneously meeting the bulk tank threshold. It may be more profitable to exceed the threshold and pay any price penalty if that results in maximum profit. If a price premium for a low SCC is paid to the farmer, then the decision to cull high SCC cows to reach the low threshold may or may not be profitable. Thus, a mathematical optimization model that maximizes farm profit subject to SCC bulk tank thresholds would be useful; in this paper, 
we specify and apply such a model to operating dairy farms.

Primary cited reasons for culling due to mastitis and high SCC count are based on reproduction and low production because both mastitis and high SCC counts are associated with low milk production and conception difficulties (Allore and Erb, 1998; Bascom and Young, 1998; Lehenbauer and Oltjen, 1998; Bar et al., 2008). Premiums resulting from lower SCC affect profits but have not been factored into previous models (Zepeda et al., 1998; Looper, 2013). In our model, we assumed that a farmer's goal is to maximize the net present value (NPV) of their herd, which is composed of the summation of the NPV of individual cows. We limit the farmer with only one remaining option to reduce SCC by culling cows from the herd, assuming that the farmer already engages in other control methods such as addressing the environment responsible for potentially high SCC and uses standard best practices. The NPV of an individual cow is influenced by such variables as lactation number and days in milk, recurrence of high SCC, reproduction, and health.

\section{MATERIALS AND METHODS}

Using data from 2 New York State dairy farms, we solved a constructed mathematical program that maximized the NPV of the herd at various SCC thresholds. The goal was to determine a herd-wide culling strategy that maximizes herd value and meets different SCC thresholds, resulting in eliminating penalties or receiving premiums for SCC threshold levels. This is a classic blending problem in which we would keep (i.e., not cull) cows that maximize profits (or minimize costs with a milk quota) while meeting a SCC threshold. The objective function is the maximization of the NPV of the herd where the decisions are to keep or cull each individual cow. It is thus a binary optimization problem. The constraint set sums total milk production and total SCC given the milk production and SCC production from each cow kept. The objective function is the maximization of total NPV of the entire herd given the NPV of each cow kept in the herd. Each cow will be retained or culled to optimize the NPV while contributing milk and SCC to the bulk tank. Thus, the primary activity in this mathematical programming model will be actions taken with specific cows where the objective value of that activity will be the NPV of that cow.

The mathematical programming model for $i$ cows in a herd of size $N$ is specified as

$$
\max \sum_{i=1}^{N}\left(N P V_{(i)} \times \delta_{k e e p(i)}\right)
$$

where $\delta_{\text {keep }(i)}$ is a binary decision variable taking the value 1 if the $i$ th cow in the herd is kept and 0 if the $i$ th cow in the herd is culled; $N P V$ is the net present value of each ith cow (in $\$$ ).

This objective function is subject to several equations and constraints:

$$
\begin{gathered}
\sum_{i=1}^{N} \text { Yield }_{(i)} \times \delta_{\text {keep }(i)}=\text { Total Milk, } \\
\sum_{i=1}^{N} S C C_{(i)} \times \text { Yield }_{(i)} \times \delta_{\text {keep }(i)}=\text { Total } S C C, \\
\sum_{i=1}^{N} \operatorname{cow}_{(i)} \times \delta_{\text {keep }(i)} \geq(1-\text { cull rate }) \times N, \\
\frac{\text { Total } S C C}{\text { Total Milk }} \leq K .
\end{gathered}
$$

The first equation sums the total milk produced by the cows retained in the herd and the second equation sums the total SCC of the cows retained. Yield is measured in liters of milk and $S C C$ is the somatic cell count per milliliter for each $i$ th cow on the test day. The third constraint requires that the number of cows retained does not exceed a defined cull rate. The cull rate is a monthly cull percentage derived from the annual average cull rate. The final constraint equation divides total herd SCC by the total herd milk production, and constrains that ratio to be less than or equal to the allowed SCC threshold value of $K$ for the bulk tank. The parameter $K$ will be varied at critical thresholds.

Modeling and solving this mathematical formulation can be implemented in many mathematical optimization software packages. We elected to use the GAMS software package (version release 24.2.1, 2013; GAMS Development Corp., Washington, DC). However, mathematical programming software is pervasive. One possibility would be to use Microsoft Excel and the Solver option in Excel (Microsoft Corp., Redmond, WA). Unfortunately, the version of Solver bundled with Excel is limited to solving a problem with only a few hundred cows and would not be an option for larger farms without purchasing an upgrade. An alternative strategy is that, on large farms, cows might be grouped by NPV, milk production, and SCC loading, with decisions based upon groups of cows.

Data were obtained from 2 farms that use DairyComp305 herd management software (Valley Agricultural Software, Tulare, CA). Collecting individual cow data on specific test days for each farm provided the 
variables necessary to implement the binary programming model: the cow's NPV, milk production, and SCC. Value per cow was captured in the model by utilizing the DairyComp305 cow value measurement that computes the NPV of each cow relative to the NPV of a replacement heifer, reported as the variable CWVAL in DairyComp305. The cow value is reported in dollars, so an animal with a CWVAL of 700 is said to be worth $\$ 700$ more than replacing her with an average first-calf heifer today. If the NPV of the replacement heifer is greater than the NPV of the current cow, then CWVAL is negative. The CWVAL is utilized for the NPV of each cow that a farm hopes to maximize across the herd by either keeping the cow in the herd or culling her and replacing her with a heifer. Because DairyComp305 is a proprietary program, we do not have details on how CWVAL is estimated. The manufacturer reported that CWVAL is a deterministic estimate of the NPV of the discounted profit from keeping the cow or replacing her with the average first-calf heifer.

Herd-level parameters included in the CWVAL estimate are the expected price of the milk sold, the marginal cost of feed, the cull value of the current cow, and the market value of a first-calf heifer. Also included in the estimate of CWVAL are expected conception risk and insemination risk, herd average replacement rates, and milk yields by parity. The individual cow parameters are numerous, but the most important are current yield, DIM, days carried calf, or days since last insemination, and age.

The CWVAL variable is only an estimate of the future NPV of a cow, given conditions known at a point in time and assumed into the future. On the data farms, many cows had negative CWVAL values, which implies these cows should be culled and replaced with a heifer. We were not able to assess the accuracy of these NPV estimates. No other estimates were readily available for the individual cows on these data farms so we elected to use the CWVAL variable as the NPV estimate. Sorge et al. (2007) assessed this value over time on 2 Ontario (Canada) farms and found CWVAL estimates for individual cows to be less stable during the first 60 DIM and for early lactations. This is logical because future pregnancy is still uncertain in the first 60 DIM and the status of future lactations is also uncertain. We used CWVAL as a decision variable to test our model compared with naïvely culling high SCC cows, acknowledging that the herdsperson may use additional information in reaching culling decisions.

Production was captured through fat-corrected yields of milk (in pounds), and SCC was determined by sampling the milk on test day to measure cells per milliliter. Milk production was converted into milliliters and multiplied by SCC (in cells $/ \mathrm{mL}$ ) to identify how each individual cow's total SCC was contributing to the loading of the bulk tank.

Given that 32 and $33 \%$ of cows are culled annually in the fifth and sixth decile, respectively, of data from 171 New York farms summarized in the 2014 New York Dairy Farm Business Summary, a constraint was added to the model to ensure that no more than $2.75 \%$ of the herd could be culled on any given monthly test date even if more than $2.75 \%$ of the cows on the 2 test farms had negative CWVAL values (Knoblauch et al., 2015). This assumes that farms have available replacements to replace up to one-third of their cows annually. Obviously, any other appropriate culling constraint value could be used, including removing this culling percentage limitation if unlimited replacement heifers could be purchased.

The cow value based on DairyComp305 was inserted as the objective function parameter in each column vector of the mathematical programming model, and the milk production and SCC for each cow were entered in appropriate rows to calculate the contribution of each cow to the SCC average of the bulk tank. The culling rate constraint was entered as a percentage of herd size. The SCC threshold constraint can be varied parametrically and the mathematical program resolved to determine the effect of various levels of SCC. If a given SCC threshold receives a price premium or penalty, that effect could be incorporated by calculating that total premium or penalty meeting the threshold, adding it to the NPV of the model meeting the threshold, and comparing it to the NPV of the model not meeting the threshold SCC levels. That would determine whether it would be profitable for the farmer to aim for a price premium or not suffer a price penalty.

The model requires these data for all cows but the study farms did not test all cows on any specific date. Thus, only a subset of the cows with complete data were used in the model. The interpretation of the results is therefore for a herd of the size and composition for which complete cow test data were available. Another interpretation might be that if the cows tested represent a random sample of cows on the farm and if the model were applied to this random sample, then the objective value could be scaled up to the entire herd. Multiple test dates with varying original SCC concentrations for the 2 herds were modeled at SCC thresholds of 400,000 and 200,000 cells/mL. Only 2 test dates are reported in this paper but the results were consistent, regardless of the test day.

\section{RESULTS AND DISCUSSION}

To evaluate the binary programming model, one test date was selected from farm $\mathrm{A}$ and one from farm B 
Table 1. Characteristics of the 2 New York State study herds

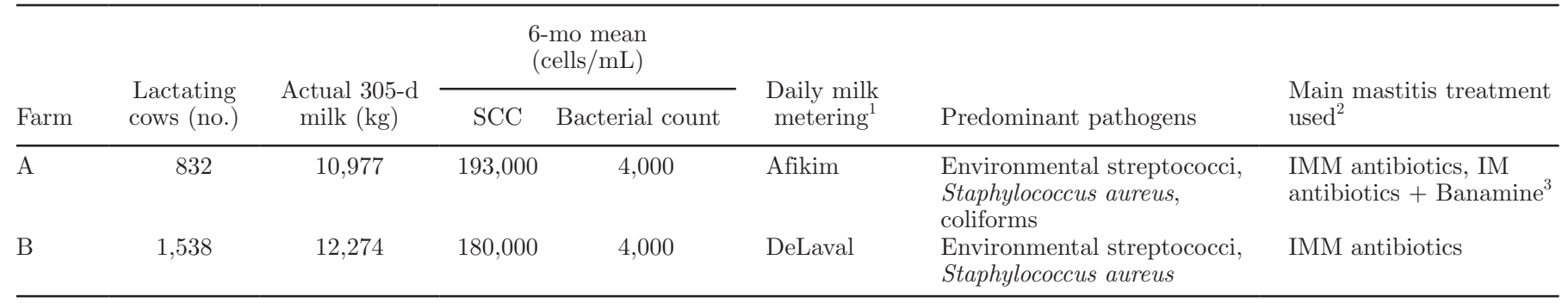

${ }^{1}$ Afikim (Kibbutz Afikim, Israel); DeLaval (Tumba, Sweden).

${ }^{2} \mathrm{IMM}=$ intramammary; $\mathrm{IM}=$ intramuscular.

${ }^{3}$ Merck Animal Health, Kenilworth, NJ.

with individual cow values, milk production, and SCC inserted into the model. The 2 farms selected were wellmanaged, high-producing Holstein herds that participated in a long-term study of mastitis (Bar et al., 2008; Cha et al., 2011; Hertl et al., 2014). Both herds are located in New York State and maintain computerized records through DairyComp305/DHIA. Both farms housed cows in freestalls and milked 3 times daily. The 2 farms have won the "Super Milk" award in New York State, criteria for which are that official SCC must be less than $250,000 / \mathrm{mL}$ for at least 10 out of 12 mo of each calendar year. Approximately $13 \%$ of New York State farms win this award in any given year. Characteristics of the 2 study herds are given in Table 1 .

On given test days for each farm, not all lactating cows are tested - only a sample of the herd have their SCC and production recorded. For farm A, we selected the test date with the highest SCC concentration, January 23, 2014, with an SCC of 253,181 cells/mL when 391 cows were tested. Because all test dates for farm A were below the 400,000 cells/mL threshold, we set the bulk tank SCC constraint to 200,000 cells $/ \mathrm{mL}$ before optimizing. Table 2 summarizes the average and standard deviations for the variables of interest, both before any culling decision and after the mathematically optimal culling decision. On the test date, an individual decision for each cow to be culled or retained was determined to maximize the overall herd NPV while meeting the constraint of the SCC threshold and culling rate.

Additionally, to demonstrate the value of optimization, we compared the results of cows culled and retained with a naïve culling strategy of culling the highest SCC cows. Under a naïve culling strategy, a farmer would sequentially eliminate cows with the highest SCC until the bulk tank threshold is met. To make the estimates consistent with the optimized results, after meeting the SCC level, additional cows were culled to match the size of the herd post-decision optimization by sequentially culling the lowest value cows. For farm A on January 23,2014 , one cow was culled under the naïve strategy but not under mathematical optimization to meet an SCC threshold of 200,000 cells/mL with an upper culling bound of $2.75 \%$ of total herd. This one alternative cow culled had a high SCC $(139,453,000$ cells $/ \mathrm{mL})$ and a negative cow value $(-\$ 423.00)$.

Figure 1 further shows the benefits of a farm maximizing NPV of the herd when meeting a threshold SCC. Two cows are denoted with their NPV next to their respective markers. Despite the fact that they have similar SCC levels, the lower-producing cow rather

Table 2. Results from optimizing profit and meeting SCC threshold of 200,000 cells/mL with upper culling bound of $2.75 \%$ of total herd (farm A, January 23,2014 , test date) ${ }^{1}$

\begin{tabular}{|c|c|c|c|}
\hline \multirow[b]{2}{*}{ Item } & \multirow{2}{*}{$\frac{\text { Pre-decision }^{2}}{\text { Herd }}$} & \multicolumn{2}{|c|}{ Post-decision $^{3}$} \\
\hline & & Cows retained & Cows culled \\
\hline $\begin{array}{l}\text { Average cow value }^{4}(\$) \\
\text { Average production }\left(\times 10^{3} \mathrm{~mL}\right) \\
\text { Total tank SCC }\left(\times 10^{3}\right) \text { contribution } \\
\text { Total tank SCC }(\text { cells } / \mathrm{mL}) \\
\text { Cows }\end{array}$ & $\begin{array}{l}313.61(793.96) \\
40.94(13.03) \\
10,365(33,078) \\
253,181 \\
391\end{array}$ & $\begin{array}{r}348.72(757.26) \\
41.08(12.90) \\
8,127(18,724) \\
197,825 \\
381\end{array}$ & $\begin{array}{c}-1,024.30(1,030.88) \\
35.43(17.19) \\
95,626(155,954) \\
2,698,727 \\
10\end{array}$ \\
\hline
\end{tabular}




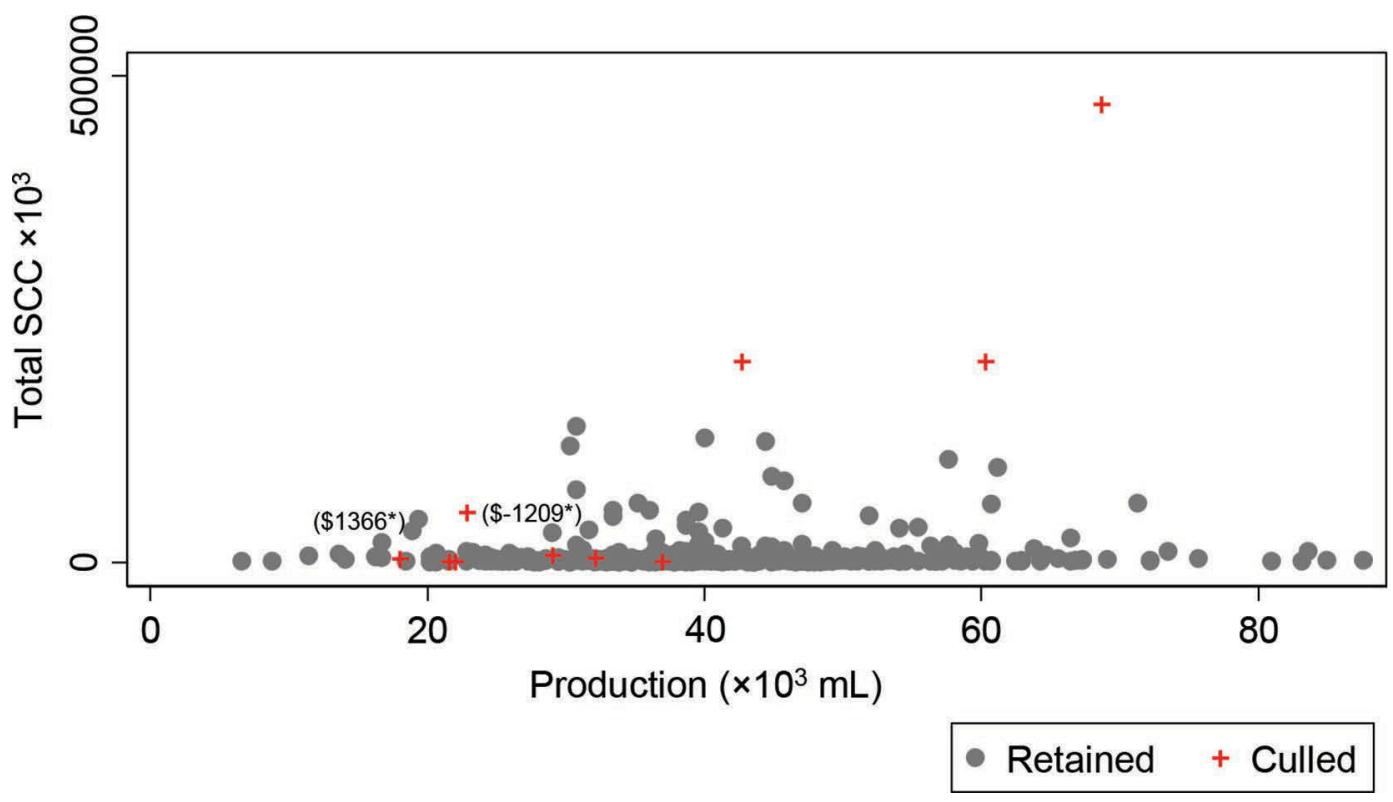

Figure 1. Post-decision after culling for optimizing profit and meeting SCC threshold of 200,000 cells/mL (farm A; January 23, 2014, test date). The net present values (NPV; $\$ 1,366$ and -\$1,209) for retained and culled cows were derived from DairyComp305 software (Valley Ag Software, Tulare, CA). A cow value can be negative if the NPV of the cow is less than that of a replacement heifer. Color version available online.

than the higher-producing cow is kept in the optimization model. This is driven by the NPV the cows add to the total herd.

A similar analysis was completed on the second farm, $\mathrm{B}$, with the data set used from the test date October 11, 2007. The bulk tank SCC on this day was 484,958 cells $/ \mathrm{mL}$ with a total of 362 cows sampled. In this case, we modeled the 400,000 cells $/ \mathrm{mL}$ threshold and, separately, the 200,000 cells/mL threshold to compare results across the varying restrictions that a milk handler may place on producers. Table 3 summarizes the average and standard deviations for the variables of interest at the 400,000 cells/mL threshold, before any culling decision and after the mathematically optimal culling decision. The post-decision statistics of retained and culled cows are what we would expect. Positive NPV cows with relatively lower SCC are not culled whereas negative NPV cows with higher SCC are culled. Individual cow decisions are made to reach the threshold maximizing herd value.

Table 4 shows 2 cows that are culled under the naïve approach but that would be retained if we optimized for herd NPV. Figure 2 shows that, under optimization, a cow with a high SCC and lesser production with zero NPV (\$0) would be retained over a cow with lower SCC and high production but a lower NPV (-\$153). Without using the mathematical optimization, the zero-NPV cow would have been culled.

The threshold was then adjusted to 200,000 cells/ $\mathrm{mL}$ and the model rerun for farm B. With the monthly

Table 3. Results from optimizing profit and meeting SCC threshold of 400,000 cells/mL with upper culling bound of $2.75 \%$ of total herd (farm B, October 11, 2007, test date) ${ }^{1}$

\begin{tabular}{lcccc}
\hline & \multicolumn{2}{c}{ Pre-decision $^{2}$} & & \multicolumn{2}{c}{ Post-decision $^{3}$} \\
\cline { 2 - 2 } \cline { 5 - 5 } \cline { 5 - 5 } Item & Herd & & Cows retained & Cows culled \\
\hline Average cow value $^{4}(\$)$ & $111.94(777.71)$ & & $127.10(774.52)$ & $-482.77(700.48)$ \\
Average production $\left(\times 10^{3} \mathrm{~mL}\right)$ & $33.59(11.06)$ & & $33.55(10.97)$ & $35.16(15.05)$ \\
Total tank SCC $\left(\times 10^{3}\right)$ contribution & $162,923(32,156)$ & & $13,402(25,048)$ & $129,640(65,061)$ \\
Total tank SCC $($ cells $/ \mathrm{mL})$ & 484,958 & & 399,416 & $3,686,578$ \\
Cows & 362 & & 253 & 9 \\
\hline
\end{tabular}

${ }^{1}$ Optimized using binary linear optimization.

${ }^{2}$ Pre-decision statistics before culling for profit and SCC; mean (SD).

${ }^{3}$ Post-decision statistics after culling for profit and SCC; mean (SD) for retained and culled cows.

${ }^{4}$ Values derived from DairyComp305 software (Valley Ag Software, Tulare, CA). A cow value can be negative if the net present value (NPV) of the cow is less than the NPV of a replacement heifer. 
Table 4. Cows culled under naïve strategy but not under mathematical optimization meeting SCC threshold of 400,000 cells $/ \mathrm{mL}$ with upper culling bound of $2.75 \%$ of total herd (farm B, October 11, 2007, test date)

\begin{tabular}{lccc}
\hline Cow ID & Cow value $^{1}(\$)$ & Production $\left(\times 10^{3} \mathrm{~mL}\right)$ & $\mathrm{SCC}\left(\times 10^{3}\right)$ \\
\hline 339 & 264.00 & 48.86 & 167,584 \\
347 & 0.00 & 51.50 & 176,642 \\
\hline
\end{tabular}

${ }^{1}$ Values derived from DairyComp305 software (Valley Ag Software, Tulare, CA). A cow value can be negative if the net present value (NPV) of the cow is less than the NPV of a replacement heifer.

$2.75 \%$ cull rate constraint, no optimal solution could be found, given that the target SCC of 200,000 cells/ $\mathrm{mL}$ is less than half of the starting SCC (484,958 cells/ $\mathrm{mL})$. The cull rate constraint was adjusted in $0.25 \%$ increments until an optimal solution was possible at a $12.25 \%$ culling rate. Table 5 summarizes the predecision and post-decision herd and, as expected, an even lower SCC is observed for retained cows than in the first case with the higher SCC threshold. Table 6 highlights 5 cows that would be culled naïvely but not under optimization. Because the threshold constraint is less than half of the original SCC and the culling rate constraint was increased, the optimal profit change was significant compared with the 400,000 cells $/ \mathrm{mL}$ solution value. Again, in visualizing the results from optimal culling in Figure 3, in cows of almost identical SCC, a cow with lower production $(-\$ 68$, to the right of point) is kept over the culled cow $(-\$ 659$, right and slightly above point), which is being driven by the NPV of each individual cow.

Table 7 summarizes the increase in profits of each herd for the 2 culling strategies for farm A on January 23, 2014, with an SCC threshold of 200,000 cells/mL, and for farm B on October 11, 2007, with SCC thresholds of 400,000 and 200,000 cells/mL. The table shows the difference in NPV of the herd depending on which method a farmer uses to meet the SCC threshold while keeping the herd size the same. The difference is not large in the first 2 cases, but over time and depending on the size of a herd, differences could be significant. With the higher original SCC on the test day for farm $\mathrm{B}$, the total increase in profit or herd value was found to be much greater the more stringent the threshold and the more cows selected for culling. However, the result with the 400,000 cells/mL threshold had a slightly larger increase in profits than in the case of farm A because of the higher initial SCC level.

It should be noted that without any restrictions on the cull rate, any cow with a negative cow value (implying she is less valuable to the herd than replacing her with a heifer) would be culled on any given test day at any SCC threshold. On some test dates on these farms, this would lead to culling close to half the herd, which would not be feasible for most farms producing their own replacement heifers. The culling rate is therefore almost always a binding constraint that results in keeping some cows with negative values, typically those that have high production, low SCC, or both. Addition-

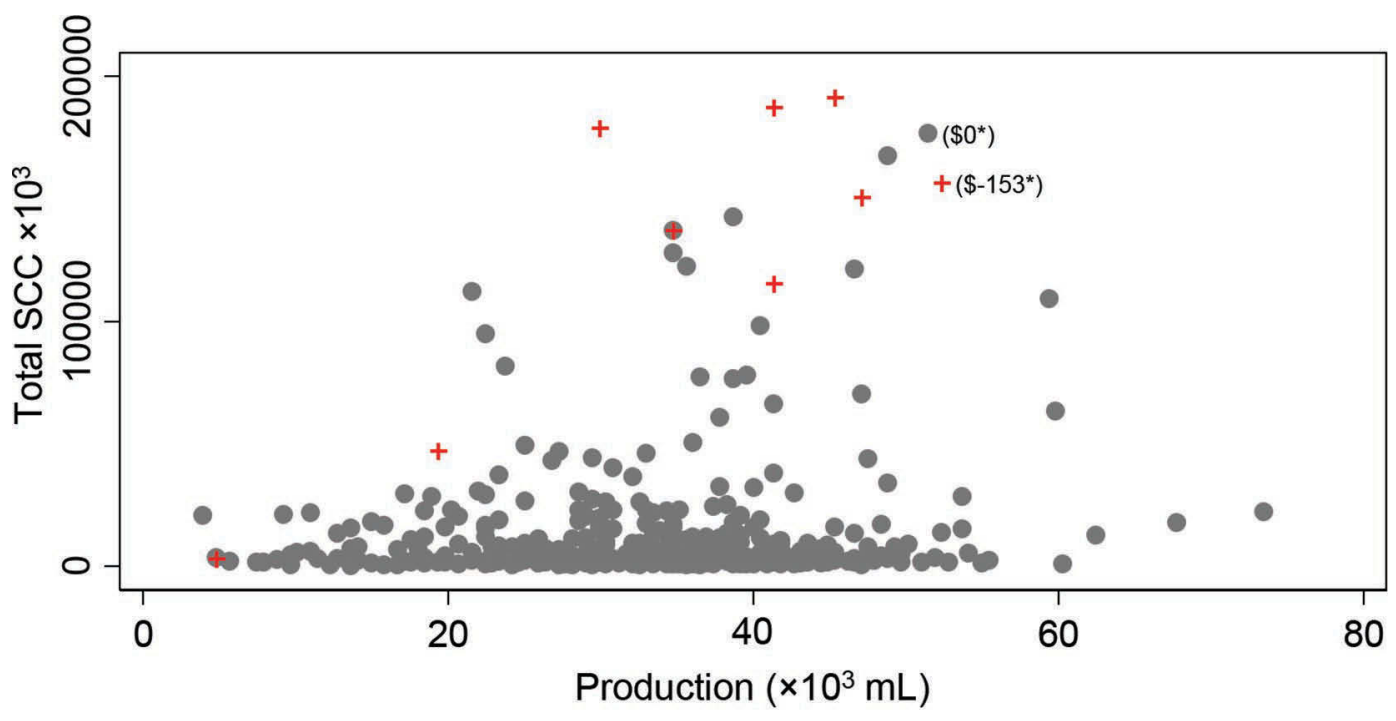

- Retained + Culled

Figure 2. Post-decision after culling for optimizing profit and meeting SCC threshold of 400,000 cells/mL (farm B; October 11, 2007, test date). The net present values (NPV; $\$ 0$ and -\$153) for retained and culled cows were derived from DairyComp305 software (Valley Ag Software, Tulare, CA). A cow value can be negative if the NPV of the cow is less than that of a replacement heifer. Color version available online. 
Table 5. Results from optimizing profit and meeting SCC threshold of 200,000 cells/mL with upper culling bound of $12.25 \%$ of total herd (farm B, October 11, 2007, test date) ${ }^{1}$

\begin{tabular}{lcccc}
\hline & \multicolumn{2}{c}{ Pre-decision $^{2}$} & & \multicolumn{2}{c}{ Post-decision $^{3}$} \\
\cline { 2 - 2 } \cline { 5 - 5 } Item & Herd & & Cows retained & Cows culled \\
\hline Average cow value $^{4}(\$)$ & $111.94(777.71)$ & & $145.79(785.75)$ & $-132.75(675.67)$ \\
Average production $\left(\times 10^{3} \mathrm{~mL}\right)$ & $33.59(11.06)$ & & $33.32(10.95)$ & $35.54(11.83)$ \\
Total tank SCC $\left(\times 10^{3}\right)$ contribution & $16,292(32,156)$ & & $6,649(7,134)$ & $85,984(51,463)$ \\
Total tank SCC $($ cells $/ \mathrm{mL})$ & 484,958 & & 199,524 & $2,419,133$ \\
Cows & 362 & & 318 & 44 \\
\hline
\end{tabular}

${ }^{1}$ Optimized using binary linear optimization.

${ }^{2}$ Pre-decision statistics before culling for profit and SCC; mean (SD).

${ }^{3}$ Post-decision statistics after culling for profit and SCC; mean (SD) for retained and culled cows.

${ }^{4}$ Values derived from DairyComp305 software (Valley Ag Software, Tulare, CA). A cow value can be negative if the net present value (NPV) of the cow is less than the NPV of a replacement heifer.

Table 6. Cows culled under naïve strategy but not under mathematical optimization meeting SCC threshold of 200,000 cells/mL with upper culling bound of $12.25 \%$ of total herd (farm B, October 11, 2007, test date)

\begin{tabular}{lccc}
\hline Cow ID & Cow value $^{1}(\$)$ & Production $\left(\times 10^{3} \mathrm{~mL}\right)$ & $\mathrm{SCC}\left(\times 10^{3}\right)$ \\
\hline 66 & 858.00 & 23.33 & 37,326 \\
104 & 510.00 & 28.61 & 30,213 \\
235 & -3.00 & 37.85 & 32,441 \\
268 & $1,593.00$ & 40.05 & 32,044 \\
294 & -68.00 & 42.70 & 29,716 \\
\hline
\end{tabular}

${ }^{1}$ Values derived from DairyComp305 software (Valley Ag Software, Tulare, CA). A cow value can be negative if the net present value (NPV) of the cow is less than the NPV of a replacement heifer. ally, we do see cows culled that have small positive cow values but high SCC. These 2 actions - keeping some cows with negative NPV and culling some cows with (small) positive NPV - give the optimization model its power and usefulness.

Additional research to further quantify the total future value of a cow's productive life with more information could improve the accuracy of each cow decision. The current model looks at that value at a single moment in time, even though managing a herd is dynamic and can quickly change. Averaging over several test dates may also give a better representation of an individual cow's contributions to the herd than at only one point in time. However, our empirical applications

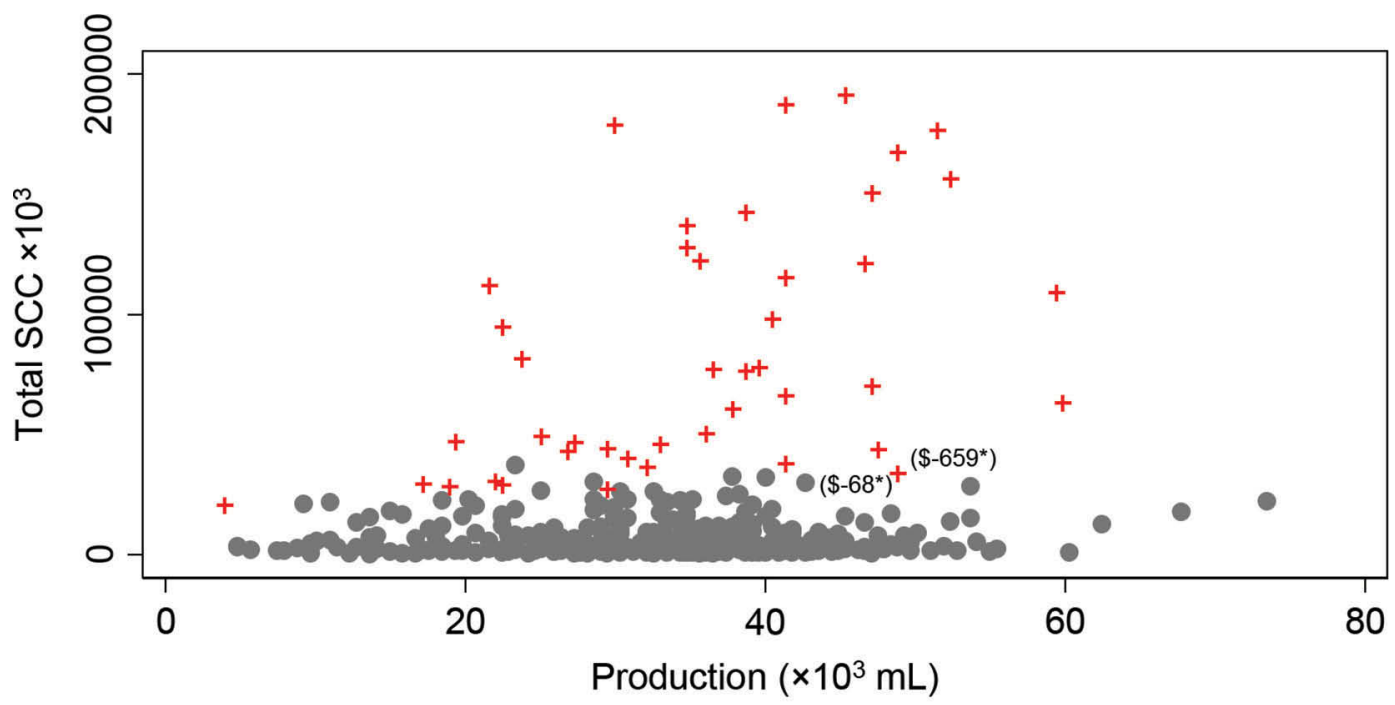

- Retained + Culled

Figure 3. Post-decision after culling for optimizing profit and meeting SCC threshold of 200,000 cells/mL (farm B; October 11, 2007, test date). The net present values (NPV; $-\$ 68$ and $-\$ 659)$ for retained and culled cows were derived from DairyComp305 software (Valley Ag Software, Tulare, CA). A cow value can be negative if the NPV of the cow is less than that of a replacement heifer. Color version available online. 
Table 7. Results from naïve and mathematical optimization culling meeting SCC thresholds of 200,000 or 400,000 cells/mL with upper culling bound of $2.75 \%$ of total herd

\begin{tabular}{lccc}
\hline & Farm A (Jan. 23, 2014): & Farm B (Oct. 11, 2007): & Farm B (Oct. 11, 2007): \\
Item & 200,000 cells $/ \mathrm{mL}$ & 400,000 cells/mL & $48000{\text { cells } / \mathrm{mL}^{3}}^{3}$ \\
\hline Original SCC $\left(\times 10^{3}\right.$ cells $\left./ \mathrm{mL}\right)$ & 253.18 & 484.96 & 48.96 \\
Mathematically optimized culling $\mathrm{NPV}^{1}(\$)$ & 132,865 & 44,868 & 46,364 \\
Naïve culling NPV $(\$)$ & 132,079 & 44,058 & 38,063 \\
Increased profit from optimal culling $(\$)$ & 786.00 & 810.00 & 8,301 \\
\hline
\end{tabular}

${ }^{1}$ Net present value (NPV) optimized using binary linear optimization.

${ }^{2}$ Cows culled naïvely (first, high-SCC cows to reach threshold, second, lowest-value cows while still meeting threshold) until herd size was equal to herd size under mathematically optimized model.

${ }^{3}$ To reach a solution, a cull rate of $12.25 \%$ was used.

still demonstrate the usefulness of making SCC culling decisions using an optimization strategy.

\section{CONCLUSIONS}

This mathematical optimization model is a step forward in identifying a sound culling model to maximize NPV for dairy farmers across an entire herd. The model shows that simply culling any cow that is above a given SCC threshold to meet a bulk tank SCC threshold may not be optimal. A more appropriate method to reach a bulk tank threshold considers an acceptable cull rate and maximizes the NPV of the herd by keeping cows or replacing culled cows with heifers. The most profitable strategy is not always to sequentially cull the cows with the highest SCC until a bulk tank SCC threshold is met. Rather, it may more profitable to keep a cow with high SCC because of her contribution to farm profitability. The model might be incorporated into current dairy computer software. An interface could be developed through which input and output can populate a mathematical program and produce individual cow results (keep or cull) that could be used by a farmer to meet the SCC threshold that maximizes the NPV of the farm. An interface would facilitate data entry and encourage utilization of empirical results. Given the dynamics of cow replacement decisions, characteristics of the cow, including parity, conception, projected milk yield, disease status, and current SCC, could be specified and, given these characteristics, the NPV of that cow could be inserted from a database of results determined by a dynamic programming model.

\section{ACKNOWLEDGMENTS}

This research was funding by the USDA National Institute of Food and Agriculture (Washington, DC), Hatch/Multistate project NYC-478841.

\section{REFERENCES}

Allore, H. G., and H. N. Erb. 1998. Partial budget of the discounted annual benefit of mastitis control strategies. J. Dairy Sci. 81:22802292. https://doi.org/10.3168/jds.S0022-0302(98)75808-4.

Allore, H. G., H. N. Erb, L. W. Schruben, and P. A. Oltenacu. 1998. A simulation of strategies to lower bulk tank somatic cell count below 500,000 per milliliter. J. Dairy Sci. 81:694-702. https://doi. org/10.3168/jds.S0022-0302(98)75625-5.

Bar, D., L. W. Tauer, G. Bennett, R. N. González, J. A. Hertl, Y. H. Schukken, H. F. Schulte, F. L. Welcome, and Y. T. Gröhn. 2008 The cost of generic clinical mastitis in dairy cows as estimated by using dynamic programming. J. Dairy Sci. 91:2205-2214. https:// doi.org/10.3168/jds.2007-0573.

Barbano, D. M., Y. Ma, and M. V. Santos. 2006. Influence of raw milk quality on fluid milk shelf life. J. Dairy Sci. 89(E. Suppl.):E15E19. https://doi.org/10.3168/jds.S0022-0302(06)72360-8.

Bascom, S. S., and A. J. Young. 1998. A summary of the reasons why farmers cull cows. J. Dairy Sci. 81:2299-2305. https://doi. org/10.3168/jds.S0022-0302(98)75810-2.

Cha, E., D. Bar, J. A. Hertl, L. W. Tauer, G. Bennett, R. N. Gonzalez, Y. H. Schukken, F. L. Welcome, and Y. T. Grohn. 2011. The cost and management of different types of clinical mastitis in dairy cows estimated by dynamic programming. J. Dairy Sci. 94:4476-4487.

Hertl, J. A., Y. H. Schukken, F. L. Welcome, L. W. Tauer, and Y. T. Gröhn. 2014. Pathogen-specific effects on milk yield in repeated clinical mastitis episodes in Holstein dairy cows. J. Dairy Sci. 97:1465-1480.

Knoblauch, W. A., C. Dymond, J. Karszes, and R. Kimmich. 2015. Dairy farm management business summary, New York State, 2014 Charles H. Dyson School of Applied Economics and Management, Cornell University, Ithaca, NY.

Lehenbauer, T. W., and J. W. Oltjen. 1998. Dairy cow culling strategies: Making economical culling decisions. J. Dairy Sci. 81:264271. https://doi.org/10.3168/jds.S0022-0302(98)75575-4.

Looper, M. 2013. Reducing somatic cell count in dairy cattle. University of Arkansas System Division of Agriculture Extension and Research FSA4002 (October). www.uaex.edu/publications/PDF/ FSA-4002.pdf.

Sorge, U. S., D. F. Kelton, K. D. Lissemore, W. Sears, and J. Fetrow. 2007. Evaluation of the Dairy Comp 305 model "Cow Value" in two Ontario dairy herds. J. Dairy Sci. 90:5784-5797. https://doi. org/10.3168/jds.2006-0813.

Zepeda, L., K. L. Buelow, K. V. Nordlund, C. B. Thomas, M. T. Collins, and W. J. Goodger. 1998. A linear programming assessment of the profit from strategies to reduce the prevalence of Staphylococcus aureus mastitis. Prev. Vet. Med. 33:183-193. https://doi. org/10.1016/S0167-5877(97)00054-8. 